Preface

\title{
Tsunami hazard along the U.S. Atlantic coast
}

Assessment of natural hazards typically relies on analysis of past occurrences of similar disaster events. Assessment of tsunami hazard to the Atlantic coast of the Unites States poses a scientific challenge because of the paucity of both historical events and prehistoric tsunami evidence. The Atlantic coast of the U.S., also known as the U.S. East Coast, is highly vulnerable to tsunami damage because major population centers and industrial facilities are located near the shoreline at low-lying elevations. This is in comparison with the Pacific coast of the United States where tsunamis are more frequent but the coastal regions are more sparsely populated and the emergent coastline has much more relief. The challenge for scientists is therefore to define and quantify the hazard for these rare events.

The special issue "Tsunami hazard along the U.S. Atlantic coast" represents the combined effort of a diverse group of marine geologists, geophysicists, geotechnical engineers, and hydrodynamic modelers to develop methods to evaluate tsunami sources with the potential to impact the U.S. Atlantic coast. Eight of the papers in this special issue present new research that was conducted as part of a Nuclear Regulatory Commission (US-NRC)-funded project to evaluate tsunami hazard to the U.S. East Coast (AMTHAG, 2008). This project supercedes Brandsma et al.'s (1979) report and provides a modern evaluation of tsunami hazard for use by electrical power utilities and the U.S.-NRC in the licensing process of new nuclear power plants. The ninth paper (Grilli et al., 2009-this issue) was written in response to an evaluation request by an insurance company.

Submarine landslides are considered the primary source of potential tsunamis along the U.S. Atlantic coast. Submarine landslides have historically generated destructive tsunamis around the world (NGDC, 2007). Tsunami run-up can be significant along coastlines proximal to landslides, as exemplified by the 1929 Grand Banks tsunami, Atlantic Canada (e.g., Fine et al., 2005), although the length of the coastline being affected by these tsunamis is much smaller than that impacted by earthquake-generated tsunamis. Submarine landslide scars and deposits are ubiquitous along the Atlantic continental slope (Twichell et al., 2009-this issue). Landslide scars are typically defined using detailed multibeam bathymetry, whereas depositional areas are often defined using side-scan sonar images. Very highresolution seismic reflection profiles help define the thickness of the deposits and cores help define the ages and geotechnical properties of the slides. Twichell et al. (2009-this issue) show that at least $33 \%$ of the continental slope and rise along the New England margin north of the Hudson Canyon is covered by landslides (excavation as well as deposition) (Fig. 1). This area is located seaward of the last maximum extent of the Laurentide ice sheet, from which large quantities of sediment were transported by major rivers to the shelf edge and slope during the last glacial period. At least 16\% of the mid-Atlantic slope and rise from the Hudson Canyon to Cape
Hatteras is covered by landslides. Here, the large rivers built shelfedge deltas along the shelf edge during the last ice age. A Jurassic salt province is located under the slope south of Cape Hatteras and its continued flow may destabilize the seafloor and cause landslides along that slope. Twichell et al. (2009-this issue) identify two types of landslides: open slope landslides, which can grow to very large areas and volumes, and canyon landslides, whose size is limited by the size of the canyon. Headwalls of open-slope landslide are often found at water depths of 2000-2500 m (Twichell et al., 2009-this issue), much deeper than the upper limit for gas hydrate stability. This observation indicates that contrary to previous suggestions (e.g., Dillon et al., 1993), these landslides were not triggered by gas hydrate dissociation due to sea level or temperature change. The ratio between volume and area of landslides along the Atlantic margin suggests that most landslides, especially those on open slope, are relatively thin (few 10s of meters) and their thickness does not increase appreciably with area (Chaytor et al., 2009-this issue).

In-depth analysis of one submarine landslide, the Currituck landslide offshore Virginia, reveals information about the stability and mobility of this landslide (Locat et al., 2009-this issue) and about its potential tsunami impact (Geist et al., 2009-this issue). The Currituck landslide is a large landslide with a total removed volume of $165 \mathrm{~km}^{3}$, and a runout distance of $180 \mathrm{~km}$ (Locat et al., 2009-this issue). Stability analysis indicates that the slide was triggered by excess dynamic pore pressure as a result of an earthquake. Considering the terminal slope angle, a simplified geometry for the slide, and Bingham viscoplastic behavior, Locat et al. (2009-this issue) calculate the development with time of the shape, velocity, and acceleration of the landslide. They conclude that the landslide had reached its peak velocity after about $8 \mathrm{~min}$ and then quickly slowed down. Realistic hydrodynamic modeling of landslide tsunamis shows that tsunami amplitude depends not only on the volume and geometry of the landslide but also on its duration (Geist et al., 2009-this issue). In other words, only the energy from the first few minutes in which the landslide moves rapidly and somewhat as a single block will be efficiently transferred to the water column. Thus, a realistic mobility analysis contributes to realistic tsunami modeling. The tsunami models presented by Geist et al. (2009-this issue) are realistic in that they are non-linear and include time development of the bottom displacement, bottom friction, and energy dissipation from wave breaking. The models show that volumes above $100 \mathrm{~km}^{3}$ are capable of generating significant runup, $>2 \mathrm{~m}$. Analysis of historic tsunami events shows that severe damage and inundation generally occur when the wave amplitude or runup at the coast reaches $1.5-2.0 \mathrm{~m}$ (Whitmore et al., 2008).

Knowledge of both the spatial and the temporal distributions of submarine landslides along the Atlantic continental margin is required in order to quantitatively evaluate the probability of the occurrence of 


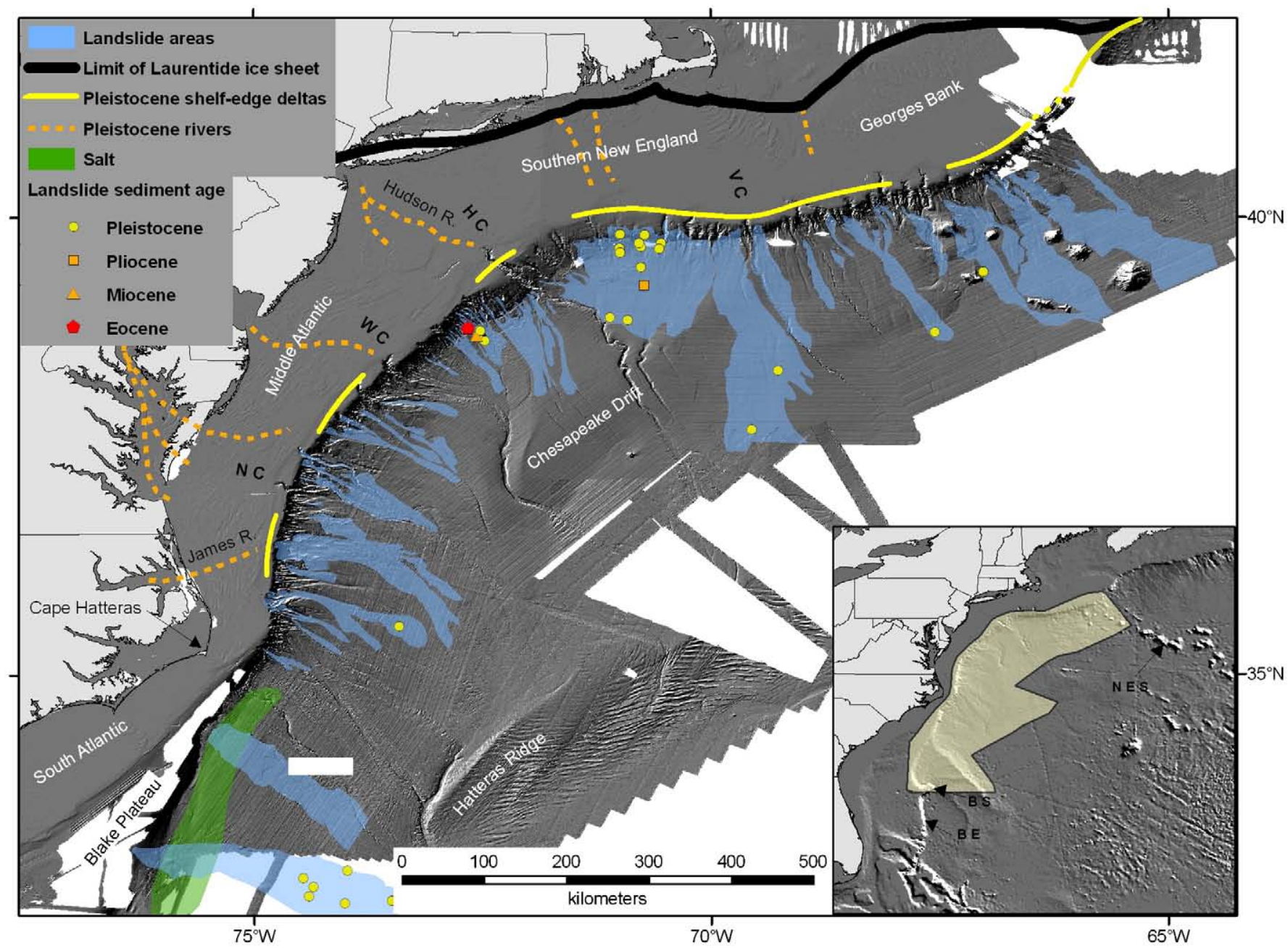

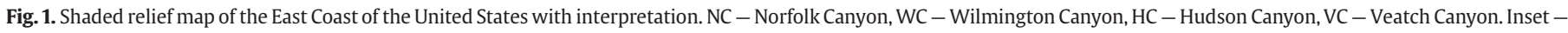

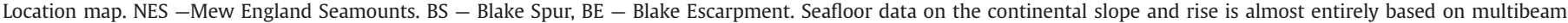
bathymetry, whereas the majority of seafloor data on the shelf is based on single-beam bathymetry. Figure courtesy of David Twichell (USGS).

landslide-generated tsunamis. A surprising observation is that landslide areas and volumes follow log-normal size distributions. For example, landslide areas of $10-100 \mathrm{~km}^{2}$ and volumes of $0.2-2 \mathrm{~km}^{3}$ are most abundant and there are fewer landslides with smaller and bigger sizes (Chaytor et al., 2009-this issue). This observation does not fit the accepted notion of an inverse power law distribution of landslide sizes (e.g., Stark and Hovious, 2001). To explain the log-normal distribution, Chaytor et al. (2009-this issue) suggest that smaller landslides are harder to identify relative to bigger ones, perhaps due to subsequent erosion, or to masking by younger landslides, and therefore the probability of landslide identification improves with increasing landslide size.

A qualitative approach to evaluating the temporal distribution of landslides is to analyze the plausible processes and factors that are likely to generate submarine landslides. Lee (2009-this issue) identifies five such processes: the amount of sediment available, the potential of these sediments to reach the slope, seismicity along the continental margin, pore pressure, and gas hydrate dissociation. He proposes that variations in the rates of these processes are governed by the glacial cycle in the northern hemisphere. For example, large volumes of sediments are expected to be generated by glacial erosion. The rate of sediment delivery to the continental slope is expected to be high during glacial time because of the proximity of the ice front to the margin, and because of the efficient subglacial and fluvial transport processes during that time. In contrast, the amount of sediment and the rate of its delivery to the slope decrease significantly during inter- glacial time. If seismicity in this intra-plate setting is driven in a large part by glacial unloading (e.g., Mazzotti and Adams, 2005), then the seismicity rate is expected to be highest during and immediately after the end of glaciation and drop later on. Lee (2009-this issue) compiles available landslide dates to show that indeed most of the dated landslides occurred during glacial time or shortly after it ended. He estimates that the rate of landslide occurrence during the past 5000 years is $0.5-3.5$ times less than during the last glacial time.

The paucity of dates and the difficulty of identifying all landslides in the bathymetric data have led to an attempt to evaluate the spatial and temporal distributions of landslides using relationships between earthquakes and landslides (ten Brink et al., 2009-this issue). Assuming that most landslides along the Atlantic continental slope were activated by earthquakes (Booth et al., 1993), ten Brink et al. (2009-this issue) propose to estimate the maximum landslide area and the maximum distance from a rupturing fault to a potential landslide, by performing pseudostatic slope stability analysis, where the slope instability is generated by ground shaking. They conclude that to trigger landslides along the continental slope, earthquakes must be located closer than $100 \mathrm{~km}$ from the slope. Therefore, with the exception of Cape Hatteras, earthquakes occurring on land are not expected to trigger continental slope landslides due to the large width of the shelf. Landslide probability can then be calculated using the probability of earthquake recurrence in the vicinity of the continental slope, which can be extracted independently from the earthquake record and from knowledge of deformation rates. 
A more formal probabilistic approach for the northern part of the U.S. Atlantic margin is taken by Grilli et al. (2009-this issue). They use a Monte Carlo approach with distributions of relevant parameters (seismicity, sediment properties, type and location, volume, and dimensions of slide, water depth, etc.) to perform large numbers of stochastic stability analyses of submerged slopes along actual shelf transects. For slopes that are deemed unstable for specified ground acceleration (with a given return period), the tsunami source characteristic height is found using empirical equations, and the corresponding breaking height and runup are estimated on the nearest coastline. Given the many simplifications that are necessary in this approach, they estimate tsunami height from 100 and 500-year landslide tsunami events, to be quite low at most locations. For the 500-year event, however two regions of peak runup were identified: $3 \mathrm{~m}$ near Long Island, NY, and $4 \mathrm{~m}$ near the New Jersey coast (Grilli et al., 2009this issue).

Geist and Parsons (2009-this issue) review the general framework for probabilistic tsunami hazard analysis (PTHA), which is derived from a similar analysis for seismic hazard (PSHA). Three steps are involved in this analysis: defining source parameters, calculating wave heights, and aggregating the results for particular coastal sites. Recurrence interval for earthquake tsunamis can be deduced from longterm rates of plate motion, and by computing histograms for different distributions of seismic coupling and of slip. For landslides, the spatial source distribution can be mapped but their recurrence rate remains elusive. One way to overcome the lack of information about recurrence interval is to link landslides with earthquake ground motions, as discussed in ten Brink et al. (2009-this issue). As an example of how tsunami propagation is incorporated into PTHA, Geist and Parsons (2009-this issue) calculate tsunami amplitude earthquakes along the Puerto Rico trench, using linear wave propagation. They show that significant amplitude is expected in some sites in the southern United States from a tsunami originating in the Puerto Rico trench, particularly landward of the Blake Ridge near Cape Fear, NC. From plate tectonics, the Puerto Rico trench is expected to have higher earthquake recurrence rates than the Azores Gibraltar zone; however, seismic coupling along the Puerto Rico trench may be very low (ten Brink, 2005; ten Brink and Lin, 2004), which would imply that most of the slip is aseismic (cf., Parsons and Geist, 2009).

The most famous earthquake in the Azores-Gibraltar convergence zone and one that generated a trans-Atlantic tsunami is the 1755 Lisbon earthquake. The tsunami was damaging not only in Europe and Africa, but also in Newfoundland, the Antilles Islands, and Brazil. However, there were no flooding reports from that tsunami in the United States. The epicenter of the earthquake is unknown and historical reports of runup amplitudes are not always reliable. Barkan et al. (2009-this issue) test various possible epicenters and fault orientations to see if the reported geographical distribution of flooding can be re-created. They conclude that a source fault, dipping to the ENE and oriented $345^{\circ}$, which is located in the center of the Horseshoe Plain, SE of Portugal, can generate the reported pattern. Tsunami emanating from this epicenter would be scattered by seafloor topography in the eastern Atlantic Ocean, and therefore waves propagating toward the U.S. East Coast would be attenuated and will likely not constitute a hazard. However, should a large earthquake occur in the Gulf of Cadiz, it could have the potential to impact the U.S. East Coast.

Work on the assessment of tsunami hazard to the U.S. East Coast continues at present and includes field efforts to map and date landslides, analysis the mobility and tsunami hazard of additional case studies in the New England margin, and an investigation of the potential of the Puerto Rico trench to create large tsunamigenic earthquakes.

\section{Acknowledgments}

I thank Eric Geist and Jason Chaytor for their constructive reviews. Work was funded by U.S.-Nuclear Regulatory Commission Job Number N6480.

\section{References}

Atlantic and Gulf of Mexico Tsunami Hazard Assessment Group (AMTHAG), 2008. Evaluation of Tsunami Sources with the Potential to Impact the U.S. Atlantic and Gulf Coasts - An Updated Report to the Nuclear Regulatory Commission. U.S. Geological Survey Administrative. Report: 300 pp.

Barkan, R., ten Brink, U.S., Lin, J., 2009. Far field tsunami simulations of the 1755 Lisbon earthquake: Implications for tsunami hazard to the U.S. East Coast and the Caribbean. Mar. Geol. 264, 109-122 (this issue).

Booth, J.S., O'Leary, D.W. Popenoe, P., Danforth, W.W. 1993. U.S. Atlantic continental slope landslides; their distribution, general attributes, and implications. In: Lee, H.J., Schwab, W.C., Twichell, D.C. (Eds.), Submarine Landslides: Selected Studies in the U.S. Exclusive Economic Zone. U.S. Geological Survey Bulletin, vol. 2003, pp. 14-22.

Brandsma, A., Divoky, D., Hwang, L., 1979. Tsunami Atlas for the Coasts of the United States. Technical Report NUREG/CR-1106. U.S. nuclear Regulatory Commission.

Chaytor, J.D., ten Brink, U.S., Solow, A.R., Andrews, B.D., 2009. Size distribution of submarine landslides along the U.S. Atlantic margin. Mar. Geol. 264, 16-27 (this issue).

Dillon, W.P., Lee, M.W., Fehlhaber, K., Coleman, D.F., 1993. Gas hydrates on the Atlantic continental margin of the United States - controls and concentration. In: Howell, D.G. (Ed.), The Future of Energy Gases. U.S. Geol. Survey Prof. Paper, vol. 1570, pp. 313-330.

Fine, I.V., Rabinovich, A.B., Bornhold, B.D., Thomson, R.E., Kulikov, E.A., 2005. The Grand Banks landslide-generated tsunami of November 18,1929; preliminary analysis and numerical modeling. In: Pelinovsky, E., Tinti, S. (Eds.), Marine Geology, pp. 45-57.

Geist, E.L., Parsons, T.A., 2009. Assessment of source probabilities for potential tsunamis affecting the U.S. Atlantic coast. Mar. Geol. 264, 98-108 (this issue).

Geist, E.L., Lynett, P.J., Chaytor, J.D., 2009. Hydrodynamic modeling of tsunamis from the Currituck landslide. Mar. Geol. 264, 41-52 (this issue).

Grilli, S.T., Taylor, O.-D.S., Baxter, C.D., Maretzki, S., 2009. A Probabilistic Approach for Determining Submarine Landslide Tsunami Hazard along the Upper East Coast of the United States. Mar. Geol. 264, 74-97 (this issue).

Lee, H.J., 2009. Timing of occurrence of large submarine landslides on the Atlantic ocean margin. Mar. Geol. 264, 53-64 (this issue).

Locat, J., Lee, H., ten Brink, U.S., Twichell, D., Geist, E., Sansoucy, M., 2009. Geomorphology, stability, and mobility of the Currituck slide. Mar. Geol. 264, 28-40 (this issue).

Mazzotti, S., Adams, J., 2005. Rates and uncertainties on seismic moment and deformation in eastern Canada. J. Geophys. Res. 110 (B9), 16.

National Geophysical Data Center (NGDC) Tsunami Database, 2007, Revised November 6, 2007, http://www.ngdc.noaa.gov/seg/hazard/tsu_db.shtml.

Parsons, T., Geist, E.L., 2009. Tsunami probability in the Caribbean region. Pure Appl. Geophys. 165, 2089-2116.

Stark, C., Hovious, N., 2001. The characterization of landslide size distribution. Geophys. Res. Lett. 28 (6), 1091-1094.

ten Brink, U.S., 2005. Vertical motions of the Puerto Rico Trench and their cause. J. Geophys. Res. 110, B06404. doi:10.1020/2004JB003459.

ten Brink, U.S., Lin, J., 2004. Stress interaction between subduction earthquakes and forearc strike-slip faults: modeling and application to the northern Caribbean plate boundary. J. Geophys. Res. 109 (B12), B12310. doi:10.1029/2004JB003031.

ten Brink, U.S., Lee, H.J., Geist, E.L., Twichell, D.C., 2009. Assessment of tsunami hazard to the U.S. East Coast using relationships between submarine landslides and earthquakes. Mar. Geol. 264, 65-73 (this issue).

Twichell, D.C., Chaytor, J.D., ten Brink, U.S., Buczkowski, B., 2009. Morphology of late Quarternary submarine landslides along the U.S. Atlantic continental margin. Mar. Geol. 264, 4-15 (this issue).

Whitmore, P., et al., 2008. NOAA/West Coast and Alaska tsunami Warning Center Atlantic ocean response criteria. Science of Tsunami Hazards 27, 1-19.

Uri S. ten Brink Guest editor

U.S. Geological Survey, Woods Hole, MA 02543, USA Tel.: +1 508 4572396; fax +1508 4572310 . E-mail address: utenbrink@usgs.gov.

11 March 2009 